\title{
Innovative tactics of industrial business in terms of economy digitalization: Case of the Republic of Belarus and the Russian Federation
}

\section{Vladimir Klimuk}

Baranovichi State University

21 Voikov St., 225404, Baranovichi, Brest Region, Republic of Belarus

PhD, Associate Professor, Vice-Rector for Scientific Work

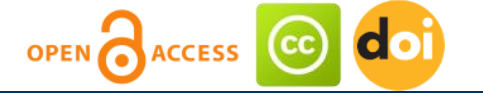

Article history:

Received: February 08, 2019

1st Revision: March 25, 2019

Accepted: April 25, 2019

JEL classification:

031

032

038

DOI:

10.14254/jems.2019.4-1.6

\begin{abstract}
As a result of growing competition in the market of industrial goods and services, the main mechanism for the sustainable development of the industry is the continuous process of creating innovations. Moreover, the creation of innovations is one of the first elements of the industry competitiveness mechanism, along with approbation of innovations and introduction into the real field of activity. Successfully past stages of testing and introducing innovations, the so-called "useful" innovations, create the basic complex of competitive advantages of the industry, its new development vector. In this paper, the author proposed assessment tools for the effectiveness of industrial policy, analyzed the calculated indicators, including using the proposed graphical tool. The article presents the types of development strategies for the new direction of industrial policy - neo-industrialization - with a set of main components of the impact on the level of development of the industry.
\end{abstract}

Keywords: innovative industrial policy, neoindustrialization, development strategy, assessment tools.

\section{Introduction}

The dynamic development of information technologies, the trend of the formation of the information society, the knowledge economy, determines the tough conditions for ensuring competitiveness in the market. These conditions, which include originality, economy, export orientation, environmental friendliness, mobility and a number of others, dictate the urgent need for rapid adaptation to market transformation, manifested in the activation of innovation activities (Teece, 2018). Thus, innovations are the dominant socio-economic growth of the country, creating

Corresponding author: Vladimir Klimuk

E-mail: klimuk-vv@yandex.ru

This open access article is distributed under a Creative Commons Attribution (CC-BY) 4.0 license. 
a platform for forcing technical and technological excellence, economic and environmental benefits, social security.

Modern society dictates the urgent necessity to "update" enterprises, assortment, and creation of innovative products. Development of innovations requires significant intellectual costs, relevant strong material and technical infrastructure, prospects of market development. Due to the increased competition, especially in the vector of technical and technological perfection, the number of unprofitable organizations increases, including those with foreign capital, that creates the conditions for economic intervention (Statistical Yearbook of the Republic of Belarus, 2019: www.belstat.gov.by). In this aspect, in order to unite forces, the resource base to increase competitiveness in the domestic and international market, cooperation of educational, scientific and business sectors is one of the implementation mechanisms (Vovk, Vovk, \& Lyashuk, 2017).

The theoretical approaches and practical aspects of the implementation of effective interaction are presented in the works of domestic and foreign researchers.

Scientist G. A. Yasheva, as one of the mechanisms of cooperation, considers the cluster concept of improving the competitiveness of enterprises with the rationale of the network cooperation mechanism and public-private partnership (on the example of light industry enterprises) (Yasheva, 2018).

N.P. Shamaeva considers the issue of cooperation of scientific and industrial organizations at the international level, considering the important role of European programs of scientific and technical cooperation, in particular, "Eureka", the Framework Program for Research and Development (Shamaeva, 2011).

In the work by R.V. Prikhodko, a method for assessing the feasibility of possible cooperation between science and production based on a system of indicators was proposed (Prikhodko, 2009).

The international scientific research is being conducted by the scientists to develop mechanisms for effective interaction between organizations of educational, scientific and business sectors (Klimuk \& Lazdins, 2019; Bregar, Puhek \& Zagmajster, 2017; Chernova \& Klimuk, 2016; Watanabe, Tou, Neittaanmaki \& Teece, 2017; Dezuanni, Foth, Mallan \& Hughes, 2018; Stoica, Pitic \& Mihaescu, 2013; Gartay, 2018; Leung, Xue \& Wen, 2019; Dufva, 2019; Liu, Nakata, Li \& Baranauskas, 2018).

J. Wiśniewska-Paluszak and G.Paluszak (2017) in the project "The model of network relationships in agribusiness» analyze and prove, on the example of agribusiness, the effectiveness of interfirm cooperation, proposing a model of network coordination that implements the goals of sustainable development. A.White considers digitization in the social sphere as the process of transformation of economy, politics and social practice (White, 2014).

The following complex should be considered as the prerequisites of interaction:

market competition,

the need to expand production,

the need to create innovation,

the ability to use scarce resources and material and technical platform,

inconsistency of development strategy of each organization,

mobility and adaptation to the changing conditions of the socio-economic system,

the requirement for continuous improvement of professional competencies and practical skills.

The countries' total desire for innovation determines the prospect of improving the quality of life, diversification of economic activities, provides barrier-free functioning of the state, on the one hand (Klimuk \& Semashko, 2019). However, there may be an increase in incidents of unfair competition, a significant "transfer" of capital from less innovative countries to innovative, which will provide an already huge gap between individual countries in economic development, on the other hand (Fig. 1). 
Figure 1: Global innovation index by country, points

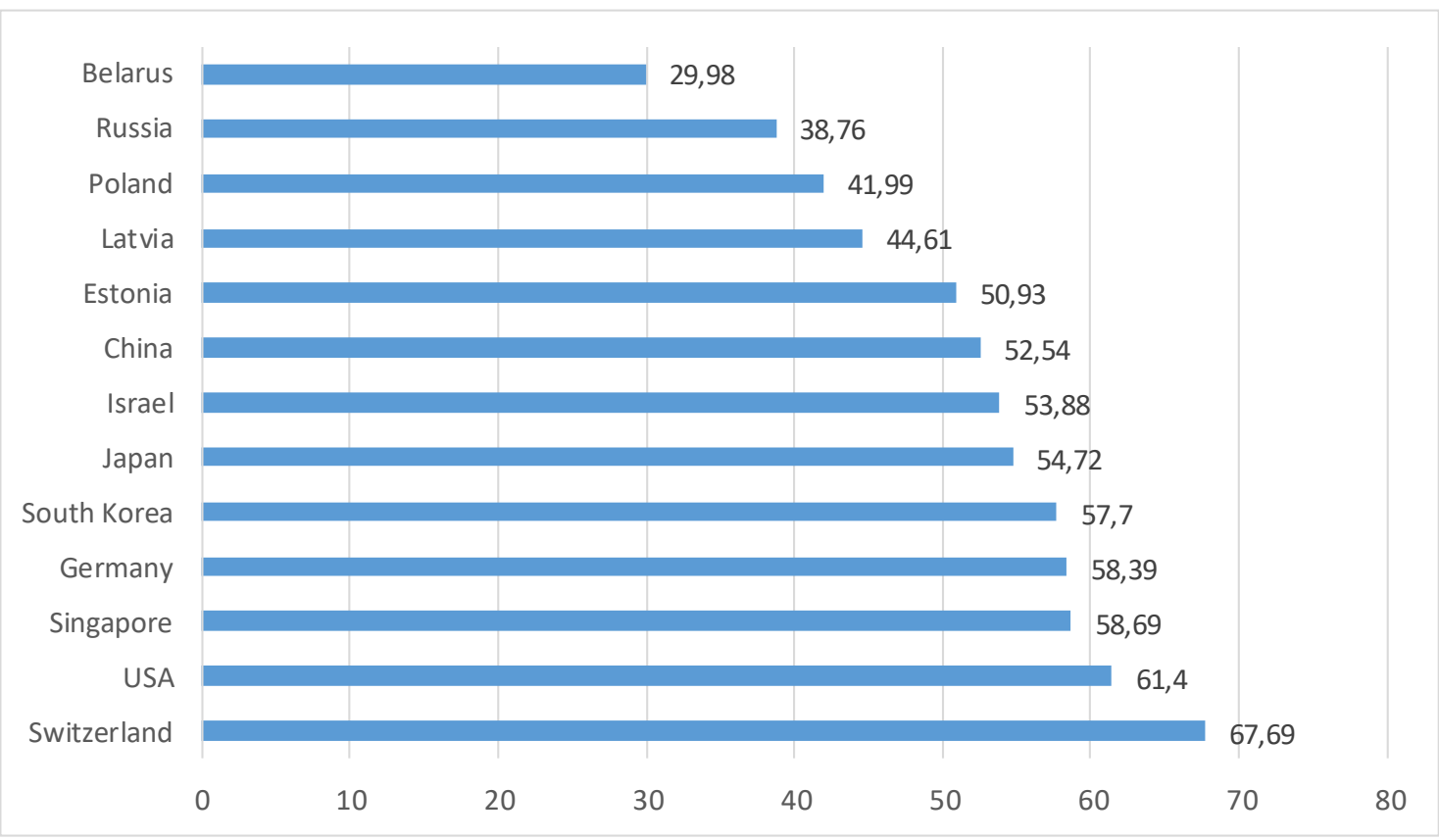

Note: INSEAD, WIPO, Cornell University: The Global Innovation Index 2017. Retrieved from https://gtmarket.ru/ratings/global-innovation-index/info

\section{Methodology}

Theoretical and methodological basis of the study are:

- principles of integrated analysis, which allowed the authors to cover a wide range of aspects of the state of the economy of Belarus and Russia and the dynamics of the processes of innovative development of industry;

- principles of system analysis, which allowed to explore measures taken to enhance innovative development at different levels of the management hierarchy of the economies of the countries of the Union State;

- comparative analysis, allowing to develop conclusions about the increase in innovation activity and draw an analogy with successful examples from foreign practice;

- an index method that allows an objective assessment of the level of innovative development of countries based on a system of developed quantitative indicators to identify structural dynamics in innovation policy.

The experiment base of the research: industrial enterprises, subjects of innovative infrastructure, national economy authorities.

The applied research methods allowed assessing the significance of the problems facing the industry and the need to develop a state approach to the formation of a new industrialization policy, relying mainly on our own strength, accumulated production and organizational potential.

For the study of a similar problem - the effectiveness of the interaction of science, education and business - a common method is the analysis of hierarchies by T. Saati, based on ranking factors (criteria) that encourage interaction, and alternatives (proposed mechanisms) for the development of this cooperation, which allows you to create possible predictive models of the development of scientific and industrial cooperation. The application of this method in practice is discussed in the work of L. Jeroshenkova (2016).

A comparative method for analyzing the experience of Russia and Belarus in the direction of digitalization of the economy in the vector of scientific and innovative development is presented in the work by J.M. Gartay "International Experience of Digitalization of the Economy: Russia and Belarus» (2018).

The idea of enhancing the creation of new models of research and innovation infrastructure is presented in the work by Dezuanni M, Foth M., Mallan K., Hughes H. "Digital Participation Through Social Living Labs: Valuing Local Knowledge, Enhancing Engagement" (Dezuanni et al., 2018).

The method of compiling technological innovations in order to transform the economy in the direction of activating the electronic economy is reflected in the work by D. Teece "Profiting from 
innovation in the digital economy: Enabling technologies, standards, and licensing models in the wireless world, Research Policy" (Teece, 2018).

The state and directions of development of digitalization processes in the education system are presented in the work by L.Bregar, Puhek M., Zagmajster M. (2017) "Analiza stanja na področju digitalizacije in e-izobraževanja v visokem šolstvu v Sloveniji".

An approach to sharing resources for economic efficiency is described in the work by Xi Y. Leung, L. Xue, H. Wen (2019) "Framing the sharing economy: Toward a sustainable ecosystem". The relevance of the application of the integrated digitalization method, in particular with regard to the social sphere, is reflected in the works (White, 2014; Dufva, 2019). The need to transform the modern economy into a digital one is noted in the works by Liu K., Nakata K., Li W., Baranauskas C. «Digitalization, Innovation and Transformation» (Liu et al., 2018), Watanabe C., Tou Yu., Neittaanmäki P. "A new paradox of the digital economy - Structural sources of the limitation of GDP statistics, Technology in Society" (Watanabe et al., 2018).

\section{Results}

The main feature of an effective model of the industry development is a complex of competitive advantages which allow the demand for created goods and services both from internal and external buyers. A sign of the indisputable advantage is innovativeness which forms possibilities of price manipulation, choice of customer segments, dictating its sales conditions, generating a set of additional services, etc. However, not all innovations are useful for the industry and cannot always influence positively on the level of its development. At the same time one should take into account the rate of changes in sales of innovative products, customer reviews, range expansion and other positions (Fig. 2).

The number of "useful" innovations in the industry, in the market and should be an indicator of its effective, qualitative innovation activity.

One of the main sectors of the economy is industry. The model of product innovativeness and processes forms a new vector of industrial development - neo-industrialization, identifying features of which are the use of new technologies:

- in production processes - to improve the products;

- in management processes - to improve the efficiency of the management system (including planning, control, operational adjustment).

For the development of the process, making qualitative decisions relating the necessary adjustments the assessment of activities in the area under study is compulsory. A system of the following indicators is proposed for the assessment of the effectiveness of neo-industrialization:

1. The rate of changes in the share of innovation products in the total volume of manufactured industrial production.

2. The rate of changes in production volume of innovative industrial products.

3. The rate of changes in investment volume in industry.

4. The rate changes in the proportion of employed workers performing researches and introducing the developments in the industrial sector in the total number of people employed in industry. industry.

5. The rate of changes in the production volume of products of V, VI technological patterns in

6. The ratio of the rate of changes in the production volume of innovative industrial products to the rate of changes in GDP.

7. The ratio of the rate of changes in the export volume of innovative industrial products to the rate of changes in the volume of imports of these products.

The complex of the indicators determines the assessment characteristic of the efficiency of the industrial sector which indicates the implementation of the "new" normality in the vector of the country's industrial development - neo-industrialization, or the established conservative model of industrial activity. 
Figure2: Indicators of "useful” information

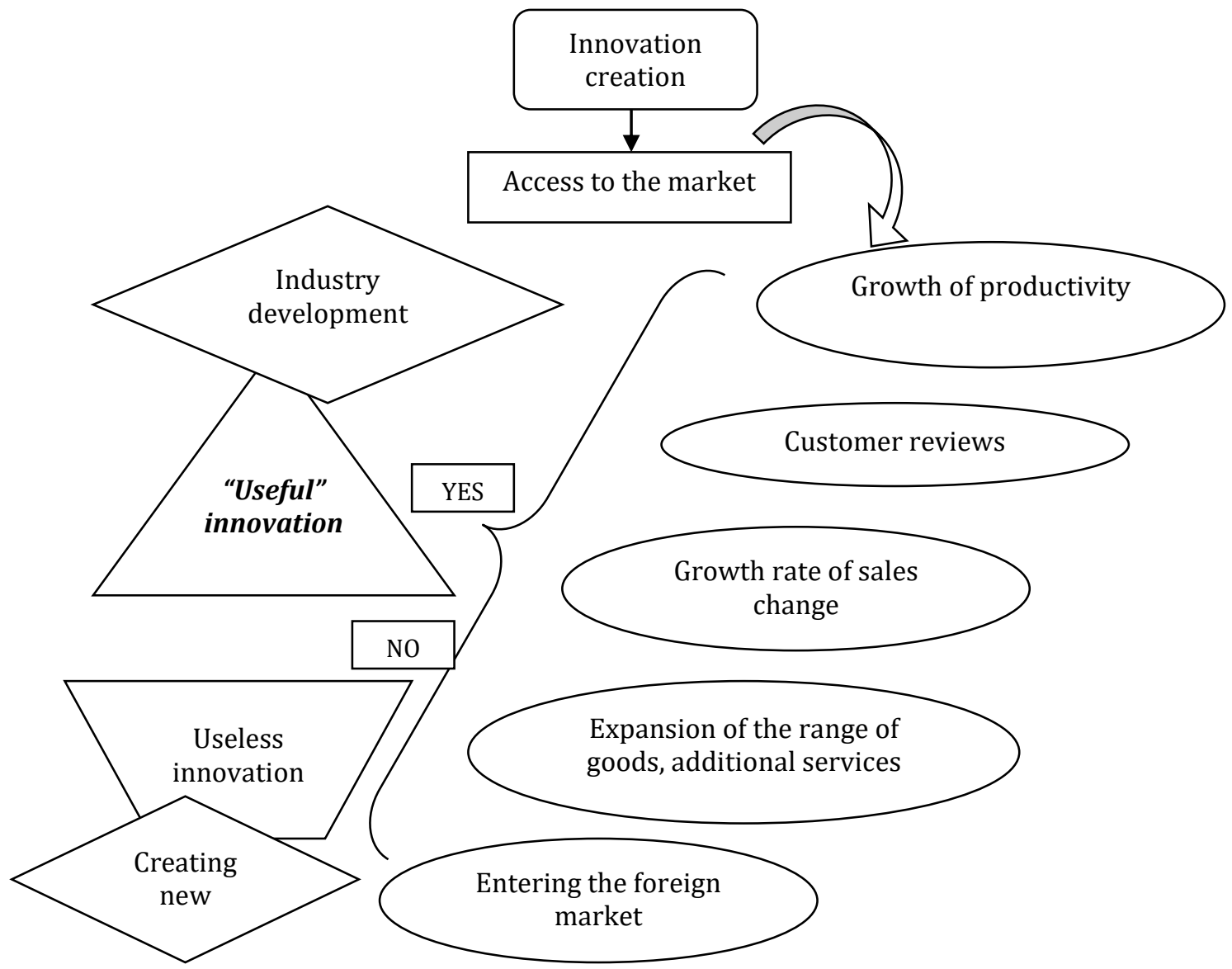

The system indicators characterize the dynamics of production and management processes in industry and indicate the dynamics in the studied area- the formation of neo-industrialization with a positive changes in the quantitative index.

In order to test the proposed assessment methods, calculations were performed in a comparative analysis of the Republic of Belarus and the Russian Federation. The results of the calculations are presented in Table 1.

Table 1: The results of calculations of the effectiveness evaluation of neo-industrialization of countries

\begin{tabular}{|c|c|c|c|c|}
\hline \multirow[t]{2}{*}{ Indicators } & \multicolumn{2}{|c|}{2016 year } & \multicolumn{2}{|c|}{2017 year } \\
\hline & Belarus & Russia & Belarus & Russia \\
\hline $\begin{array}{l}\text { 1. The rate of changes in the share of innovation products } \\
\text { in the total volume of manufactured industrial production } \\
\text { (Sinv) }\end{array}$ & 1.03 & 1.05 & 1.07 & 1.06 \\
\hline $\begin{array}{l}\text { 2. The rate of changes in production volume of innovative } \\
\text { industrial products (Rinnov) }\end{array}$ & 1.12 & 1.10 & 1.25 & 1.17 \\
\hline $\begin{array}{l}\text { 3. The rate of changes in investment volume in industry } \\
\text { (Sind) }\end{array}$ & 1.03 & 1.01 & 1.05 & 1.02 \\
\hline $\begin{array}{l}\text { 4. The rate changes in the proportion of employed } \\
\text { workers performing researches and introducing the } \\
\text { developments in the industrial sector in the total number } \\
\text { of people employed in industry (Rs) }\end{array}$ & 0.98 & 1.01 & 1.03 & 1.02 \\
\hline $\begin{array}{l}\text { 5. The rate of changes in the production volume of } \\
\text { products of } V \text {, VI technological patterns in industry (Rp) }\end{array}$ & 1.12 & 1.15 & 1.35 & 1.19 \\
\hline $\begin{array}{l}\text { 6. The ratio of the rate of changes in the production } \\
\text { volume of innovative industrial products to the rate of } \\
\text { changes in GDP (RGDP) }\end{array}$ & 1.05 & 1.08 & 1.12 & 1.11 \\
\hline $\begin{array}{l}\text { 7. The ratio of the rate of changes in the export volume of } \\
\text { innovative industrial products to the rate of changes in the } \\
\text { volume of imports of these products (Rexp) }\end{array}$ & 0.95 & 1.01 & 0.98 & 1.01 \\
\hline Integral index & 1.04 & 1.06 & 1.12 & 1.08 \\
\hline
\end{tabular}


To visualize the results of the calculations, it is proposed to use a vector diagram that clearly reflects the current and changing state of the proposed indicators, which, as a result, allows you to make decisions quickly regarding the adjustments made to management and production processes based on the identified weaknesses (Fig. 2).

Figure2: Dynamics of constituent elements of neo-industrialization vector in country segment, 2017

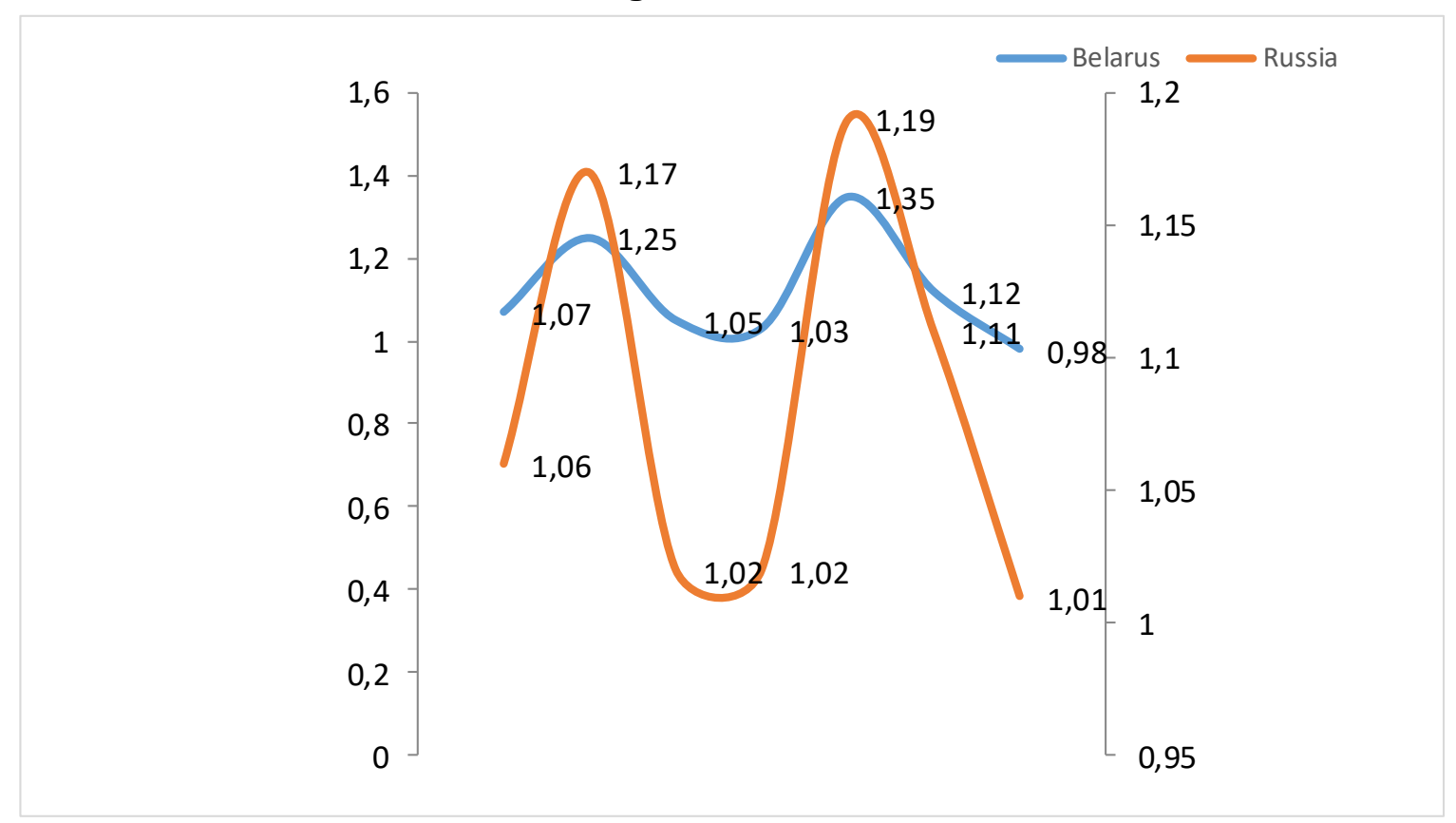

Source: Statistical Yearbook of the Republic of Belarus, 2018

In general, the innovative development of the industrial sector is characterized by positive dynamics in 2017:

- in the Republic of Belarus - by 7.7 per cent;

- in the Russian Federation - by 1.9 per cent.

Of particular note is a significant increase in production volumes of industrial products based on new and high technologies (V, V I technological patterns).

As "weaknesses" in the direction of neo-industrialization, we should highlight the indicator of labor resources, carrying out research and development in the industrial sector, as well as the excess of innovation import over export.

In order to level the first problem, it is necessary to stimulate research and innovation activity among the personnel of industrial organizations. The following tools for stimulating are offered: rating point payment system for employees; organization of joint fundamental, applied research; bonuses for scalability, export orientation, search for potential customers, etc.)To solve the second problem, it is necessary to implement the direction of cooperation of scientific organizations, organizations of the industrial sector to form a research and production cluster, realizing the principle of synergy of performance results, also consider the possibility of creating joint international research and production (network) alliances aimed at manufacturing V, VI technological patterns.

\section{Conclusions}

The implementation of the neo-industrialization vector can be based on the choice of one of the following strategies:

1. Cloning - the use of borrowed technology in the industrial sector to improve the efficiency of production and management processes.

2. Active - strengthening the policy of innovation, focusing on the development of the innovation platform (activities of the subjects of the innovation infrastructure), the phased introduction of innovations, the intensification of research and development.

3. Passive -- the use of ready-made foreign innovative solutions (without creating own, new). 
Thus, the proposed methodology for assessing the effectiveness of neo-industrialization is a tool for the operational management of the innovation policy of a country (region), forming a set of specific objectives and mechanisms for the development of the system.

An active neo-industrialization strategy is aimed at the formation and development of the innovative component of the country in a separate industry with access to the intersectoral level, forming a network of comprehensive innovation in the country.

\section{Appendix A. Supplementary material}

Supplementary data associated with this article can be found, in the online version, at https://doi.org/10.14254/jems.2019.4-1.6

\section{Funding}

The authors received no direct funding for this research.

\section{Citation information}

Klimuk, V. (2019). Innovative tactics of industrial business: Case of the Republic of Belarus and the Russian Federation. Economics, Management and Sustainability, 4(1), 58-65. doi:10.14254/jems.2019.4-1.6

\section{References}

Bregar, L., Puhek, M., Zagmajster, M. (2017). Analiza stanja na področju digitalizacije in eizobraževanja v visokem šolstvu v Sloveniji. Maribor, DOBA Fakulteta. Retrieved from http://www.doba.si/ftp/dokumenti/fakulteta/gradiva/Bregar_Puhek_2017_IKTvVS.pdf.

Chernova, O.A., \& Klimuk, V.V. (2016). Factors and determinants of the innovative development of the national economy in the imperatives of industrialization. In Materials of the 3rd International Political and Economic Congress and the 6thInternational Scientific and Practical Conference "Russia in the Global Economy: Challenges and Development Institutions", Rostovon-Don, May 26-28, 2016, 169-177.

Dezuanni, M, Foth, M., Mallan, K., \& Hughes, H. (2018). Digital participation through social living labs: Valuing local knowledge, enhancing engagement. Cambridge, MA, United States: Chandos Publishing, an imprint of Elsevier.

Dufva, T., \& Dufva, M. (2019). Grasping the future of the digital society. Futures, 107, 17-28. Retrieved from https://doi.org/10.1016/j.futures.2018.11.001. (http://www.sciencedirect.com/science/article/pii/S0016328717302252)

Gartay, J.M. (2018). International Experience of Digitalization of the Economy: Russia and Belarus. Working Paper, Modern Eurasian Studies, 1, 15-23.

Jeroscenkova, L. (2016). The use of cultural heritage for the development of rural tourism. Doctoral thesis for the scientific degree. Jelgava.

Klimuk, V., \& Lazdins, A. (2019). Interaction of education, science and business in terms of digital economy development. In Proceedings of the 2019 International Conference "Economic science for rural development, No 52, Jelgava, LLU ESAF, 9-10 May 2019, 37-45 (https://doi.org/10.22616/ESRD.2019.102).

Klimuk, V.V. (2016). Modernization concepts of industrial development. Socio-Economic Problems and State, 2, 51-58.

Klimuk, V.V., \& Semashko, M. Yu. (2018). Innovatization of industrial business in the direction of integration with education and science. Economic Trends, 1-9. Retrieved from http://ej.barsu.by/download/1//3_7.pdf.

Leung, X. Y., Xue, L., \& Wen, H. (2019). Framing the sharing economy: Toward a sustainable ecosystem. Tourism Management, https://doi.org/10.1016/j.tourman.2018.09.021. (http://www.sciencedirect.com/science/article/pii/S0261517718302358).

Liu, K., Nakata, K., Li, W., \& Baranauskas, C. (2018). Digitalization, innovation and transformation: 18-th IFIP WG 8.1 International Conference on Informatics and Semiotics in Organizations, 
ICISO 2018, Reading, UK, July 16-18, 2018, Proceedings. Retrieved from https://doi.org/10.1007/978-3-319-94541-5.

Neborsky, E.V. (2017). Reconstruction of the university model: Transition to the 4.0 format. Mir nauki, 17(4), 1-10. Retrieved from https://mir-nauki.com/PDF/26PDMN417.pdf.

Prikhodko, R.V. (2009). Network research and production cooperation of higher educational institutions and industrial enterprises [Setevaia nauchno-proizvodstvennaia kooperatsiia vysshikh uchebnykh zavedenii i promyshlennykh predpriiatii]. Economics and environmental management = Ekonomika i ekologicheskii menedzhment, 2, 34-43.

Shamaeva, N.P. (2011). The role of research and production cooperation for an innovative type of economic growth [Rol nauchno-proizvodstvennoi kooperatsii dlia innovatsionnogo tipa ekonomicheskogo rosta]. Vestnik Udmurtskogo universiteta. Ekonomika i pravo = Bulletin of Udmurt University. Economy and Law, 4, 83-86.

Statistical Yearbook of the Republic of Belarus, 2018 (2018) Retrieved from http://www.belstat.gov.by/en/ofitsialnaya-statistika/publications/statistical-publicationsdata-books-bulletins/public_compilation/index_12543/.

Teece, D. J. (2018). Profiting from innovation in the digital economy: Enabling technologies, standards, and licensing models in the wireless world. Research Policy, 47(8), 1367-1387. https://doi.org/10.1016/j.respol.2017.01.015.

(http://www.sciencedirect.com/science/article/pii/S0048733318300763)

Vovk, I., Vovk, Y., \& Lyashuk, O. (2017). Improvement of the organizational-economic mechanism of resource-saving at the machine building enterprise. Economics, Management and Sustainability, 2(2), 6-14. doi:10.14254/jems.2017.2-2.1

Watanabe, C., Tou, Y., \& Neittaanmäki, P. (2018). A new paradox of the digital economy-Structural sources of the limitation of GDP statistics. Technology in Society, 55, 9-23. https://doi.org/10.1016/j.techsoc.2018.05.004. (http://www.sciencedirect.com/science/article/pii/S0160791X17302385)

White, A. (2014). Digital media and society: transforming economics, politics and social practices. Springer.

Wiśniewska-Paluszak, J. \& Paluszak, G. (2017). The model of network relationships in agribusiness. Retrieved from https://www.researchgate.net/project/The-model-of-networkrelationships-in-agribusiness

Yasheva, G. A. (2010). Cluster concept of improving the competitiveness of enterprises in the context of network cooperation and public-private partnership: monograph. Vitebsk: VSTU.

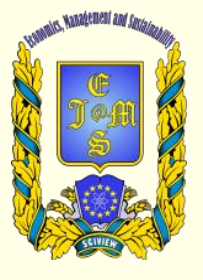

(c) 2016-2019, Economics, Management and Sustainability. All rights reserved.

This open access article is distributed under a Creative Commons Attribution (CC-BY) 4.0 license.

You are free to:

Share - copy and redistribute the material in any medium or format Adapt - remix, transform, and build upon the material for any

purpose, even commercially.

The licensor cannot revoke these freedoms as long as you follow the license terms.

Under the following terms:

Attribution - You must give appropriate credit, provide a link to the license, and indicate if changes were made.

You may do so in any reasonable manner, but not in any way that suggests the licensor endorses you or your use.

No addition

You may not apply legal terms or technological measures that legally restrict others from doing anything the license permits.

Economics, Management and Sustainability (ISSN: 2520-6303) is published by Scientific Publishing House "CSR",

Poland, EU and Scientific Publishing House "SciView", Poland

Publishing with JEMS ensures:

- Immediate, universal access to your article on publication

- High visibility and discoverability via the JEMS website

- Rapid publication

- Guaranteed legacy preservation of your article

- Discounts and waivers for authors in developing regions

Submit your manuscript to a JEMS at http://jems.sciview.net or submit.jems@sciview.net



